\title{
Biochemical parameters of wild felids (Panthera leo and Panthera tigris altaica) kept in captivity
}

\author{
Parâmetros bioquímicos de felídeos selvagens \\ (Panthera leo e Panthera tigris altaica) mantidos em cativeiro
}

\author{
Maria Helena Matiko Akao Larsson ${ }^{1 *}$; Auddrey Sismotto Flores ${ }^{2}$; José Daniel \\ Luzes Fedullo ${ }^{3}$; Rodrigo Hidalgo Friciello Teixeira ${ }^{4}$; Regina Mieko Sakata \\ Mirandola ${ }^{2}$; Fumio Honma Ito ${ }^{1}$; Rebecca Bastos Pessoa ${ }^{2}$; Paula Hiromi Itikawa ${ }^{2}$
}

\begin{abstract}
Most populations of wild felines are now considered endangered or near extinction due to the indiscriminate hunting and the reduction of their natural habitat, caused by man. Due to the limited number of animals within a population, these species are especially vulnerable to the impacts of diseases and endogamy. In addition, wild felines are also susceptible to metabolic and behavioral changes related to a change in their natural conditions, habitat, and feeding, when the animal enters into captivity. There are few descriptions in the literature of the serum biochemistries of lions and tigers. This study presents the biochemical parameters of 23 captive lions (Panthera leo) and 10 captive Siberian tigers (Panthera tigris altaica) from the Zoological Park of the Sao Paulo Foundation. Serum urea, creatinine, total protein, albumin, total, direct and indirect bilirubin were measured. In addition, serum levels of ALT, AST, ALP, GGT, glucose, CK, lactate dehydrogenase, cholesterol, and triglycerides were determined, as well as calcium, phosphorus, chlorine, sodium, and potassium. Biochemical parameters did not differ significantly among males and females lions, but higher albumin values were observed in male Panthera tigris altaica in comparison to females. The values obtained in this study may be used as reference for captive individuals of Panthera leo and Panthera tigris altaica.
\end{abstract}

Key words: Electrolytes. Glucose. Hepatic profile. Renal profile.

\section{Resumo}

A maioria das populações de felinos selvagens é considerada ameaçada ou em extinção devido à caça indiscriminada e à redução de seu habitat natural causada pelo homem. Devido ao número limitado de animais, essas espécies são vulneráveis às doenças e endogamia, além das alterações metabólicas e comportamentais relacionadas à mudança das condições naturais, habitat e alimentação e, ainda, à condição de cativeiro. Há poucos relatos na literatura sobre a bioquímica sérica em leões e tigres. Este estudo apresenta os parâmetros bioquímicos de 23 leões de cativeiro (Panthera leo) e 10 tigres siberianos de cativeiro (Panthera tigris altaica) do Fundação Parque Zoológico de São Paulo. Ureia; creatinina; AST; ALT; ALP; GGT; bilirrubinas total, direta e indireta; proteína total; albumina; CK; lactato desidrogenase; triglicérides, de colesterol e de glicose séricas foram determinados; e bem como os eletrólitos cálcio, fósforo, cloro, sódio e potássio. Não foram encontradas diferenças de parâmetros

\footnotetext{
${ }^{1}$ Profs., Faculdade de Medicina Veterinária e Zootecnia, Universidade de São Paulo, FMVZ/USP, São Paulo, Brasil. E-mail: akaolar@usp.br; fumio@usp.br

2 Pesquisadores, Faculdade de Medicina Veterinária e Zootecnia, FMVZ/USP, São Paulo, UF, Brasil. E-mail: auddrey@ig.com.br; regina@usp.br; rebecca.pessoa@usp.br; paulaitikawa@usp.br

${ }^{3}$ Médico Veterinário, Fundação Parque Zoológico de São Paulo, São Paulo, SP, Brasil. E-mail: jdfedullo@yahoo.com.br

${ }^{4}$ Médico Veterinário, Parque Zoológico Municipal Quinzinho de Barros, Sorocaba, SP, Brasil. E-mail: rhftz00@hotmail.com

* Author for correspndence
} 
bioquímicos relacionados ao sexo de Panthera leo, mas para Panthera tigris altaica foram observados valores mais elevados de albumina em machos. Os valores obtidos neste estudo podem ser usados como referência para os indivíduos em cativeiro de Panthera leo e Panthera tigris altaica.

Palavras-chave: Eletrólitos. Glicose. Perfil hepático. Perfil renal.

\section{Introduction}

Lions (Panthera leo or Felis leo) are naturally present in Africa; thirty years ago there were 200,000 individuals, and currently there are between 15,000 and 32,000 animals that inhabit regions of the savanna and semidesert. There are several subspecies, some of which are already extinct. Tigers (Panthera tigris) are found in South Asia, mainly in the jungle areas of India. There are many subspecies including: Panthera tigris tigris (Bengal tiger), which has an estimated population of less than 2,500 wild animals; Panthera tigris altaica (Siberian tiger), with 150-450 animals in the wild, and 500-700 animals within zoos around the world; and Panthera tigris sumatrae (Sumatran tiger), with only 400-500 individuals in the wild and about 340500 animals in protected areas. There are other subspecies as well, some of which are already extinct. All of them, without exception, are endangered.

Lions and tigers have been the subject of intense research. The study of clinically healthy individuals within a population is an important method for acquiring normal parameters. These data are particularly relevant when working with endangered populations, since the data serve as a benchmark for the evaluation of health and physiology of both the individual animal and the general population (CHUNDAWAT et al., 2011; LINKIE et al., 2013; MAAS et al., 2013). Amounts of many substances such as substrates, metabolites, enzymes, electrolytes, metals, and hormones, among others, within blood can be determined by biochemical methods.

The biochemical parameters measured in this study were chosen due to their importance in aiding the diagnosis of several diseases in both domestic and wild animals.
It is known that blood urea nitrogen (BUN) and creatinine are non-protein nitrogen substances that are normally filtered from the blood by the kidney and excreted in the urine, and that their elevation may indicate azotemia.

In regards to the hepatic function analysis, the importance of measuring aspartate aminotransferase (AST) and alanine aminotransferase (ALT) is to aid in the diagnosis of liver injury, injury of skeletal muscles, cardiac muscle injury, and strenuous exercise. Increased alkaline phosphatase (ALP) increase in circulation may be indicative of biliary obstruction (intra- or extrahepatic), hepatic damage, and disease of bone tissue (HILL, 2011). Gamma glutamyl transferase (GGT) is increased either in cases of cholestasis or biliary necrosis. In cats, GGT is a more sensitive indicator of cholestatic disease than ALP (BAIN, 2009).

Another important substance to be quantified is bilirubin. Hyperbilirubinemia may result from increased production (pre-hepatic, increase in indirect bilirubin), decreased conjugation and storage (hepatic, increase in both direct and indirect bilirubin), or decreased elimination (post-hepatic, increase in direct bilirubin) (SCHLESINGER; RUBIN, 1993).

Regarding the serum glucose levels, increases may be related to Diabetes mellitus, hyperadrenocorticism, acromegaly, pheochromocytoma, and glucagonoma, whereas hypoglycemia may be associated with endotoxemia, marked exertion, hepatic insufficiency, starvation, hypoadrenocorticism, and some neoplasias (BAIN, 2009).

Besides that, other measurements such as serum creatine kinase (CK) activity are important to assess skeletal muscle damage, and to a lesser 
extent, myocardial injury. Serum LDH (lactate dehydrogenase) changes may be due mainly to damage of the liver and of skeletal and cardiac musculature (BAIS; PHILCOX, 1994). Lactate is formed primarily as the end product of anaerobic glycolysis. Liver disease, kidney disease, Diabetes mellitus, sepsis, certain drugs and toxins, and uncommon mitochondrial defects can cause lactic acidosis (ALLEN; HOLM, 2008).

The evaluation of the fat metabolism is made through the quantification of triglycerides (TGs) and cholesterol. TGs are significantly increased in primary biliary cirrhosis, high fat diets, Diabetes mellitus, hypothyroidism, acute pancreatitis, cholestasis, and starvation (GUNN-CHRISTIE; EASLEY, 2009).

This study aimed to evaluate some biochemical parameters of captive lions (Panthera leo) and Siberian tigers (Panthera tigris altaica) from a Zoological Park in Brazil. The tests permormed included quantitative ones for renal function (urea and creatinine), liver function (total protein, albumin, AST, ALT, ALP, GGT and bilirubin direct, indirect and total), muscle function (CK and LDH), lipids (total cholesterol and triglycerides), electrolytes (calcium, phosphorus, sodium, and potassium), and others substances, such as glucose.

\section{Materials and Methods}

Twenty-three adult lions (Panthera leo), including fourteen males and nine females, and ten adult Siberian tigers (Panthera tigris altaica), including five males and five females, were biochemically evaluated.

The felines were clinically examined through mucosae inspection, evaluation of skin elasticity, cardiopulmonary auscultation, blood pressure measurement, and lymph nodes palpation. Animals under treatment, with inadequate body condition, dehydrated, infested by ectoparasites and/or affected by any other disease were excluded. Measurements of sodium, potassium, and chloride were only performed in twenty lions and four tigers due to technical limitations.

The animals were chemically restrained on their own premises using anesthetic darts containing ketamine $^{\mathrm{a}}$ and xylazine ${ }^{\mathrm{b}}$ at doses of $10 \mathrm{mg} \mathrm{kg}^{-1}$ and 1-2 $\mathrm{mg} \mathrm{kg}^{-1}$, respectively.

An appropriate volume (20-25 mL) of blood intended for biochemical evaluation was collected by jugular, cephalic, or saphenous venipuncture.

The biochemical exams were processed using the Medical System Analyserc. Urea was measured by UV enzymatic method ${ }^{\mathrm{d}}$, according to Talke \& Schubert (1965) and creatinine through modified Jaffet's method (LUSTGARTEN; WENK, 1972).

Regarding the liver function analysis, total protein was measured by the biuret method (GORNALL et al., 1949), albumin through modified bromocresol green method, according to Corcoran and Durham (1977) and bilirubin by the manual method $^{\text {e }}$ of diazotization, according to Jendrassik and Grof (1938).

Alanine aminotransferase was assessed by UV cinectic method ${ }^{\mathrm{f}}$, according to Bergmeyer et al. (1986), aspartate aminotransferase through UV cinectic method", according to Bergmeyer et al. (1986) and alkaline phosphatase: cinectic colorimetric method ${ }^{\mathrm{h}}$, according to Ceriotti et al. (2002). Gamma glutamyl transferase was measured using cinectic colorimetric method, according to Shaw et al. (1983).

\footnotetext{
a Dopalen - Sespo Divisão Vetbrands Saúde Animal - Brazil.

b Sedazine - Fort Dodge Saúde Animal Ltda. - Brazil.

c Model "Lyasis"

d item 10310022 - Diasys- Germany

e CELM - Brazil.

f item 11533 - Biosystems - Spain.

g item 11531 - Biosystems - Germany.

h item 11518 - Byosistems - Spain.

i item 11520 - Biosystems - Spain.
} 
Glucose was quantified by the enzymatic method ${ }^{j}$ of glucose oxidase peroxidase, according to Barham and Trinder (1972), whereas creatinine kinase was assessed using UV cinectic method, according to Horder et al. (1991). LDH quantification was made according to Bais and Philcox (1994), using commercial kit ${ }^{\mathrm{k}}$, and cholesterol quantification was performed by the enzymatic colorimetric method, according to Allain et al. (1974).

Triglycerides was measured using the enzymatic colorimetric method ${ }^{\mathrm{m}}$, according to Fossati and Prencipe (1982), calcium was quantified by complexometry $^{\mathrm{n}}$, according to Michaylova and Ilkoa (1971), phosphorus was asseded using the colorimetric method in $\mathrm{UV}^{\mathrm{o}}$, according to Muñoz et al., (1983).

Finally, chlorine quantification was performed by a colorimetric method, according to Velapoldi et al. (1979 a), whereas sodium and potassium were assessed by the manual method by flame photometry, according to Velapoldi et al. (1978) and Velapoldi et al. (1979 b), respectively.
For statistical analysis, the variables sex and species were analyzed using unpaired student $\mathrm{T}$ test was performed using Graph Pad Instat version 2.01 for Windows 95, Graph Pad Software, San Diego, California, USA, considering statistically significant $\mathrm{p}<0.05$.

\section{Results}

Due to the significant number of animals enrolled, it was possible to establish mean values and the respective standard deviations of the data acquired. Due to the homogeneity of the ages of the individuals examined, it was not possible to stablish the possible influence of the age in the values obtained, but the variable sex was investigated.

No differences were found concerning the sex of Panthera leo, but with Panthera tigris altaica higher albumin values were observed in males. The results are expressed as mean and standard deviation for each species (Tables 1 and 2).

item 11503 - Biosystems - Spain.

k item 11581 - Biosystems - Spain.

1 item 11505 - Biosystems - Spain.

m item 11528 - Biosystems - Spain.

n item 11570 - Biosystems - Spain.

o item 11508 - Biosystems - Spain. 
Table 1. Means and standard deviations for the biochemical parameters of captive lions (Panthera leo).

\begin{tabular}{|c|c|c|c|c|c|c|}
\hline \multirow{2}{*}{ Biochemical parameter } & \multicolumn{2}{|c|}{ Lions $(\mathrm{n}=22)$} & \multicolumn{2}{|c|}{ Males(n=13) } & \multicolumn{2}{|c|}{ Females $(n=9)$} \\
\hline & Mean & SD & Mean & SD & Mean & SD \\
\hline Albumin $\left(\mathrm{g} \mathrm{dL}^{-1}\right)$ & 3.372 & 0.55 & 3.307 & 0.622 & 3.465 & 0.444 \\
\hline $\operatorname{ALP}\left(\mathbf{U ~ L}^{-1}\right)$ & 42.497 & 46.662 & 27.648 & 35.507 & 62.296 & 54.205 \\
\hline $\operatorname{ALT}\left(\mathbf{U ~ L}^{-1}\right)$ & 62.66 & 39.104 & 72.925 & 47.882 & 47.832 & 12.500 \\
\hline $\operatorname{AST}\left(\mathbf{U ~ L ~}^{-1}\right)$ & 53.999 & 36.432 & 63.173 & 43.822 & 40.748 & 16.406 \\
\hline $\mathrm{DB}\left(\mathrm{mg} \mathrm{dL} \mathbf{L}^{-1}\right)$ & 0.038 & 0.044 & 0.031 & 0.046 & 0.044 & 0.042 \\
\hline IB (mg dL $\left.{ }^{-1}\right)$ & 0.288 & 0.377 & 0.337 & 0.481 & 0.186 & 0.054 \\
\hline TB $\left(\mathrm{mg} \mathrm{dL}^{-1}\right)$ & 0.327 & 0.378 & 0.368 & 0.485 & 0.230 & 0.059 \\
\hline Calcium (mg dL $\left.{ }^{-1}\right)$ & 7.714 & 2.062 & 7.520 & 2.233 & 7.994 & 1.878 \\
\hline $\mathbf{C K}\left(\mathbf{U ~ L ~ L}^{-1}\right)$ & 225.883 & 172.719 & 172.153 & 56.630 & 291.553 & 240.875 \\
\hline Cholesterol (mg dL dL $\left.^{-1}\right)$ & 158.954 & 36.540 & 154.370 & 42.157 & 165.574 & 27.486 \\
\hline Creatinine (mg dL $\left.{ }^{-1}\right)$ & 3.295 & 1.131 & 3.514 & 1.410 & 2.978 & 0.428 \\
\hline Phosphorus (mg dL $\left.{ }^{-1}\right)$ & 8.124 & 13.986 & 5.112 & 0.688 & 12.476 & 21.834 \\
\hline Glucose $\left(\mathrm{mg} \mathrm{dL}^{-1}\right)$ & 128.455 & 23.227 & 132.692 & 24.370 & 122.333 & 21.307 \\
\hline LDH $\left(\mathbf{U ~ L}^{-1}\right)$ & 142.860 & 127.020 & 177.158 & 158.870 & 97.128 & 38.901 \\
\hline Total Protein (g dL dL $\left.^{-1}\right)$ & 7.431 & 0.573 & 7.467 & 0.664 & 7.378 & 0.442 \\
\hline Triglycerides (mg dL $\left.\mathrm{dL}^{-1}\right)$ & 52.499 & 16.086 & 52.103 & 16.212 & 53.070 & 16.863 \\
\hline Urea $\left(\mathrm{mg} \mathrm{dL}^{-1}\right)$ & 74.966 & 20.484 & 81.979 & 22.372 & 64.836 & 12.463 \\
\hline Sodium (mMol.L - $\left.^{-1}\right)^{*}$ & 149,6 & 9,659 & 147,818 & 5,618 & 151,778 & 13,132 \\
\hline Potassium (mMol.L $\left.{ }^{-1}\right)^{*}$ & 3,81 & 0,288 & 3,864 & 0,307 & 3,744 & 0,265 \\
\hline Chloride (mMol.L $\left.{ }^{-1}\right) *$ & 126,7 & 4,194 & 127,091 & 4,206 & 126,222 & 4,381 \\
\hline
\end{tabular}

$\mathrm{SD}=$ Standard deviation; $*=$ for these parameters, Lions $(\mathrm{n}=20)$, Males $(\mathrm{n}=11)$ and Females $(\mathrm{n}=9)$.

Table 2. Means and standard deviations for the biochemical parameters of captive Siberian tigers (Panthera tigris altaica).

\begin{tabular}{|c|c|c|c|c|c|c|}
\hline \multirow{2}{*}{ Biochemical parameter } & \multicolumn{2}{|c|}{ Tigers $(n=10)$} & \multicolumn{2}{|c|}{ Males $(n=5)$} & \multicolumn{2}{|c|}{ Females $(n=5)$} \\
\hline & Mean & SD & Mean & SD & Mean & SD \\
\hline Albumin $\left(\mathrm{g} \mathrm{dL}^{-1}\right)$ & 3.715 & 0.392 & 3.97 & 0.26 & 3.457 & 0.364 \\
\hline $\operatorname{ALP}\left(\mathbf{U ~ L}^{-1}\right)$ & 55.169 & 35.619 & 42.71 & 33.55 & 67.630 & 37.104 \\
\hline $\operatorname{ALT}\left(\mathbf{U ~ L ~ L}^{-1}\right)$ & 59.271 & 23.582 & 54.79 & 8.98 & 63.754 & 35.203 \\
\hline $\operatorname{AST}\left(\mathbf{U ~ L}^{-1}\right)$ & 29.662 & 14.234 & 28.91 & 9.69 & 30.418 & 19.690 \\
\hline DB $\left(\mathrm{mg} \mathrm{dL}^{-1}\right)$ & 0.053 & 0.037 & 0.05 & 0.04 & 0.055 & 0.043 \\
\hline IB (mg dL $\left.{ }^{-1}\right)$ & 0.126 & 0.055 & 0.14 & 0.05 & 0.107 & 0.060 \\
\hline TB $\left(\mathrm{mg} \mathrm{dL}^{-1}\right)$ & 0.189 & 0.071 & 0.19 & 0.08 & 0.182 & 0.067 \\
\hline Calcium (mg dL $\left.{ }^{-1}\right)$ & 8.751 & 0.217 & 8.67 & 0.02 & 8.835 & 0.326 \\
\hline $\mathbf{C K}\left(\mathbf{U ~ L ~ L}^{-1}\right)$ & 267.992 & 94.891 & 237.79 & 68.07 & 298.196 & 120.159 \\
\hline Cholesterol (mg dL $\left.{ }^{-1}\right)$ & 186.694 & 32.742 & 193.04 & 32.75 & 180.346 & 35.197 \\
\hline Creatinine $\left(\mathbf{m g ~ d L} \mathbf{L}^{-1}\right)$ & 3.382 & 0.340 & 3.34 & 0.11 & 3.422 & 0.521 \\
\hline Phosphorus (mg dL $\mathbf{~}^{-1}$ ) & 5.544 & 0.418 & 5.70 & 0.32 & 5.350 & 0.516 \\
\hline Glucose (mg dL $\left.\mathbf{L}^{-1}\right)$ & 188.900 & 47.192 & 210 & 39.29 & 167.8 & 50.246 \\
\hline $\mathbf{L D H}\left(\mathbf{U ~ L ~}^{-1}\right)$ & 143.825 & 23.983 & 147.62 & 27.29 & 140.032 & 21.698 \\
\hline Total Protein $\left(\mathrm{g} \mathrm{dL}^{-1}\right)$ & 6.935 & 0.469 & 7.02 & 0.37 & 6.851 & 0.598 \\
\hline Triglycerides $\left(\mathrm{mg} \mathrm{dL}^{-1}\right)$ & 38.234 & 10.172 & 34.13 & 2.87 & 42.340 & 14.362 \\
\hline Urea $\left(\mathbf{m g ~ d L} \mathbf{L}^{-1}\right)$ & 55.456 & 18.359 & 63.04 & 5.45 & 47.872 & 25.722 \\
\hline Sodium (mMol.L L $\left.^{-1}\right)^{*}$ & 143,5 & 2,958 & - & - & - & - \\
\hline Potassium (mMol.L $\left.{ }^{-1}\right)^{*}$ & 3,625 & 0,370 & - & - & - & - \\
\hline Chloride (mMol.L $\left.{ }^{-1}\right)^{*}$ & 123 & 7,176 & - & - & - & - \\
\hline
\end{tabular}

$\mathrm{SD}=$ Standard deviation; $*=$ for these parameters, Tigers $(\mathrm{n}=4)$. 


\section{Discussion}

There are few descriptions in the literature on serum biochemistry values in lions and tigers. One of the main sources of information to veterinarians and biologists working with these species is the International Species Information System (ISIS). The values obtained in this study may enrich the amount of information available, and benefit monitoring of individuals, thus favoring the conservation of these species.

There was a similarity between the albumin, cholesterol and total protein determinations obtained in our study and the values obtained by Maas and coworkers (2013), or those available from the ISIS database, which refer to captive animals.

The anesthetic protocol may influence the biochemical parameters measured in different animal species. Currier and Russell (1982) evaluated serum bilirubin values obtained in Felis concolor and compared the values to those obtained from domestic cats. According to Seal et al. (1987), plasma bilirubin levels are influenced by anesthesia with high doses of xylazine in Bengal tigers. Total protein levels obtained in this study were similar to those referenced by Seal et al. (1987) for Panthera tigris tigris that were also anesthetized with ketamine and xylazine.

Diniz and Amaral (1982) compared the protein, total and fractional, content of the wild cat (Felis pardinoides) and jaguar (Panthera onca), and later determined the protein, total and fractional, concentration in the serum of lions (Panthera leo), also comparing the values between males and females.

In relation to gender differences, the higher albumin values that were observed in male tigers may be partially explained by the ingestion of larger quantities of meat when compared to females.

A discrepancy found between the results obtained for Panthera leo in the present study and in the literature refers to the levels of BUN and serum creatinine, which were consistently higher in the present study. Weaver and Johnson (1995) found a single difference in serum urea levels between males and females of Lynx felis canadensis, higher in males, possibly due to pre-clinical renal dysfunction that was related to a declining age.

Panthera leo serum creatinine and BUN levels were the only values that disagreed with the serum biochemistry values described for free-ranging Felis concolor coryi by Dunbar et al. (1997).

The BUN values obtained for Panthera tigris altaica were similar to those described by Shrivastav et al. (2012) for the same species. The individuals used by Shrivastav et al. (2012) came from natural reserves in India, which decreases the reliability of comparisons between BUN values obtained during the present study, given the differences between the feeding habits of wild and captive animals.

Changes in serum creatinine may be associated with diet, muscle damage, and the amount of muscle mass (MORSE; FOLLIS, 1973; MILLER et al., 1999). Unlike what was observed by Miller et al. (1999) in Felis rufus, no difference was found in serum biochemistry parameters between males and females in this study. Miller et al. (1999) observed higher values of BUN in males, and higher creatinine levels in females.

Higher AST values were found in lions. Nevertheless tests of hepatic injury should be interpreted with caution in felines, since ALT varies according to the methods and instruments used (DUNCAN et al., 1994), and AST is not very effective for detecting hepatic diseases. Moreover, ALT in felines may be increased in cases of hyperthyroidism, leading to a false positive diagnosis of liver disease (MERIC, 1986).

Nevertheless, the importance of assessing the AST and ALT levels remains to aid in the diagnosis of liver injury, skeletal muscles injuries (due to trap capture, restraint stress, or dart immobilization (SEAL et al., 1987), cardiac muscle injury, and strenuous exercise. 
Seal et al. (1987) described AST values in Bengal tigers that are similar to those obtained in this study. Regarding the females, lower AST values were found in the present study for both Panthera leo and Panthera tigris altaica, in comparison to the fidings of Widmer et al. (2012). Nevertheless, on the referred studies, not only the species difference must be considered, but also the different handling techniques used on the animals, which may influence the results obtained.

Blood glucose was lower in Panthera tigris individuals, and the triglycerides level was higher in comparison with Panthera leo. These results may be characteristic of each species, but the duration of the fasting period at the time of blood collection and any possible endocrine disturbances should be considered.

Low levels of cholesterol are observed in cases of liver failure, therapy with anticonvulsants, and low fat diets (BUSH, 2004). According to Currier and Russel (1982), cholesterol is an endpoint for captive animals that are kept in confined locations have lower activity levels, and are fed a different diet than wild individuals of the same species.

Increased concentrations of cholesterol are related to elevation of lipoproteins. These elevations can occur as a primary condition, or secondarily because of Diabetes mellitus, hypothyroidism, Cushing's syndrome, high-fat diets, starvation, and blockage of the bile ducts.

The values obtained for phosphorus, LDH, and triglycerides were similar to those described for Panthera tigris tigris anesthetized with ketamine and xylazine by Seal et al. (1987). Cholesterol and glucose differed between the previously mentioned paper and the present study, but feeding behaviours, capture method, and handling of the individuals may limit the possibility of comparison.

Currier and Russel (1982) related an increase in blood creatinine phosphokinase (CPK) to increased muscle activity in Felis concolor, since this enzyme is used primarily in the diagnosis of muscle injury.
Currier and Russell (1982) related increased serum $\mathrm{LDH}$ to muscle injuries in mountain lions (Felis concolor).

In acute hypocalcemia, the condition appears to be most closely associated with the mechanism of calcium regulation than with the supply of calcium. Hypercalcemia has been associated with breast carcinoma in several species, whereas moderate hypercalcemia may be secondary to primary renal disease. Characteristic hypercalcemia (without hyperphosphatemia) is related to the secretion of humoral factors produced by tumors or induced by metastases, especially those of bone origin (HARRESTEIN et al., 1996). High concentrations of calcium in the blood are also attributed to growth activity in Felis rufus (MILLER et al., 1999). Acute clinical imbalance of calcium is associated with tetany or eclampsia, whereas chronic imbalances are associated with disorders of bone formation.

Hypophosphatemia may reflect malabsorption, vitamin D deficiency, primary hyperparathyroidism, or diuresis, among others (DUNCAN et al., 1994). Hyponatremia can be caused by excessive sodium loss (emesis and diarrhea, renal failure, diuretic therapy, osmotic diuresis), overhydration (polydipsia, acute renal failure) and relative overhydration (increased blood pressure, decreased colloid osmotic pressure) (BUSH, 2004).

No difference was observed between sodium levels of free-ranging and captive Felis concolor, and small variations were explained by diet differences (CURRIER; RUSSEL, 1982). Morse and Follis et al. (1973) did not find different sodium levels between males and females of Panthera leo. Hypernatremia can be caused by excessive water loss (vomiting, diarrhea, dehydration, Cushing's syndrome, protein rich diet, and polyuria), a deficiency in water consumption, and excessive exercise. 


\section{Conclusions}

Standardization of blood biochemistry values allows the use of these parameters to monitor health status in wild animals, and favors the conservation of endangered species. The values obtained in this study may be used as reference for captive individuals of Panthera leo and Panthera tigris altaica.

Nevertheless, handling and feeding habits of an animal should be taken into consideration when analyzing blood biochemistry results, since many variables may influence these data. Anesthetic protocol and age of the animal may also be important factors.

\section{References}

ALLAIN, C. C.; POON, L. S.; CHAN, C. S. G.; RICHMOND, W.; FU, P. C. Enzymatic determination of total serum cholesterol. Clinical Chemistry, Salt Lake City, v. 20, n. 4, p. 470-475, 1974.

ALLEN, S. E., HOLM, J. L. Lactate: physiology and clinical utility. Journal of Veterinary Emergence and Critical Care, San Antonio, v. 18, n. 2, p. 123-32, 2008.

BAIN, J. B. Topics. In: VADEN, S. L.; KNOLL, J. S.; SMITH, F. W. K.; TILLEY. L. P. Blackwell's five-minute veterinary consul: laboratory tests and diagnostics procedures. Iowa: Blackwell Publishing Ltd, Oxford, 2009. p. 322-323.

BAIS, R.; PHILCOX, M. International Federation of Clinical Chemistry IFCC). Approved recommendation on IFCC methods for the measurement of catalytic concentrations of enzymes. Part 8. IFCC method for lactate dehydrogenase. European Journal of Clinical Chemistry and Clinical Biochemistry, Oxford, v. 32, n. 8, p. 639-655, 1994.

BARHAM, D.; TRINDER, P. An improved colour reagent for the determination of blood glucose by oxydase system. Analyst, London, v. 97, n. 151, p. 142-145, 1972.

BERGMEYER, H. U.; HORDER, M.; REJ, R. International Federation of Clinical Chemistry. Approved recommendations (1985) on IFCC for the measurements of catalytic concentrations of enzymes. Journal of Clinical Chemistry and Clinical Biochemistry, Oxford, v. 24, n. 7, p. 481-495, 1986.
BUSH, B. W. Enzimologia. In: Interpretação de resultados laboratoriais para clínicos de pequenos animais. São Paulo: Roca, 2004. p. 233-261.

CERIOTTI, F.; BONORA, R.; GUERRA, E.; FERRERO, C. A.; SERENA, C.; CAROBENE, A.; PANTEGHINI, M. Amino-methyl-propanol (AMP) and N-methylglucamine (MEG) buffers for alkaline phosphatase (ALP) measurement: effects on human samples and control materials. Clinical Chemeitry and Laboratory Medicine, Berlim, v. 40, p. 222-223, 2002. Supplement.

CORCORAN, R. M.; DURHAM, S. M. Albumin determination by a modified bromocresol green method. Clinical Chemistry, Salt Lake City, v. 23, n. 4, p. 765766, 1977.

CURRIER, M. J. P.; RUSSEL, K. Hematology and blood chemistry of the mountain lion. Journal of Wildlife Diseases, Lawrence, v. 18, n. 1, p. 99-104, 1982.

DINIZ, L. S. M.; AMARAL, A. D. do. Estudo comparativo do teor proteico total e fracionado em duas especies da família Felidae - Felis pardinoides Gray, 1867 gato do mato e Panthera onca Linnaeus, 1758. Boletim de Fisiologia Animal, Sao Paulo, v. 6, n. 6, p. 127-141, 1982.

DUNBAR, M. R.; NOL, P.; LINDA, S. B. Hematologic and serum biochemical reference intervals for Florida panthers. Journal of Wildlife Diseases, Lawrence, v. 33, n. 4, p. 783-789, 1997.

DUNCAN, J. R.; PRASSE, K. W.; MAHAFFEY, E. A. Veterinary laboratory medicine. Iowa: Iowa State University Press, 1994. 300 p.

FOSSATI, P.; PRENCIPE, L. Serum triglycerides determined colorimetrically with an enzyme that produces hydrogen peroxide. Clinical Chemistry, Salt Lake City, v. 28, n. 10, p. 2077-2080, 1982.

CHUNDAWAT, R. S.; KHAN, J. A.; MALLON, D. P. Panthera tigris $s s p$. tigris. In: IUCN 2011. IUCN Red List of Threatened Species. Version 2011.2. Available at: <www.iucnredlist.org>. Accessed at: 10 dec. 2016.

GORNALL, A. G.; BARDAWILL, C. J.; DAVID, M. M. Determination of serum protein by means of biuret method. Journal of Biological Chemistry, Maryland, v. 177, n. 2, p. 751-766, 1949.

GUNN-CHRISTIE, R. G.; EASLY, J. Topics. In: VADEN, S. L.; KNOLL, J. S.; SMITH, F. W. K.; TILLEY, L. P. Blackwell's five-minute veterinary consul: laboratory tests and diagnostics procedures. Iowa: Blackwell Publishing Ltd., Oxford, p. 645-647, 2009. 
HARRESTEIN, L. A.; MUNSON, L.; SEAL, U. S. Mammary cancer in captive wild felids and risk factors for its development: a retrospective study of the clinical behavior of 31 cases. Journal of Zoo and Wildlife Medicine, Yulee, v. 27, n. 4, p. 468-176, 1996.

HILL, M. E. Doenças inflamatórias do fígado. In: AUGUST, J. R. Medicina interna de felinos. 6. ed. Rio de Janeiro: Elsevier Editora Ltda, 2011. p. 215-226.

HORDER, M.; ELSER, R. C.; GERHART, W.; MATHIEU, M.; SAMPSON, E. J. International federation of clinical chemistry, committee on enzymes. Approved recommendation on IFCC methods for the measurement of catalytic concentration for enzymes. Part 7. IFCC method for creatine kinase. European Journal of Clinical Chemistry and Clinical Biochemistry, Oxford, v. 29, n. 7, p. 435-456, 1991.

JENDRASSIK, L.; GROF, P. Vereinfachte photometrische Methoden zur Bestimmung des Blutbilirubins. Biochemistry Zeitschrift, Berlim, v. 257, n. 88, p. 81-89, 1938.

LINKIE, M.; WIBISONO, H. T.; MARTYR, D. J.; SUNARTO, S. Panthera tigris ssp. sumatrae. In: IUCN 2013. IUCN red list of threatened species. Version 2013. Available at: <www.iucnredlist.org>. Accessed at: 10 dec. 2016.

LUSTGARTEN, J. A.; WENK, R. E. Simple, rapid, kinetic method for serum creatinine measurement. Clinical Chemistry, Salt Lake City, v. 18, n. 1, p. 14191422, 1972.

MAAS, M.; KEETT, D. F.; NIELEN, M. Hematologic and serum chemistry reference intervals for free-ranging lions (Panthera leo). Research in Veterinary Science, Amsterdam, v. 95, n. 1, p. 266-268, 2013.

MERIC, S. M.; HAWKINS, E. C.; WASHABAU, R. J.; TURREL, J. M.; FELDMAN, E. C. Serum thyroxine concentrations after radioactive iodine therapy in cats with hyperthyroidism. Journal of the American Veterinary Medical Association, Schaumburg, v. 188, n. 9, p. 1038-1040, 1986.

MICHAYLOVA, V.; ILKOA, P. Photometric determination of micro amounts of calcium with arsenazo III. Anatytica Chimica Acta, Amsterdam, v. 53, n. 1, p. 194-198, 1971.

MILLER, D. L.; LEOPLOLD, B. D.; GRAY, M. J.; WOODY, B. J. Blood parameters of clinically normal captive bobcats (Felis rufus). Journal of Zoo and Wildlife Medicine, Yulee, v. 30, n. 2, p. 242-247, 1999.

MORSE, R. W.; FOLLIS, T. B. Physiologic normals research in lions. The World's Cats, Winston, v. 2, n. 1, p. 189-200, 1973.
MUÑOZ, M. A.; BALÓN, M.; FERNANDÉZ, C. Direct determination of inorganic phosphorus in serum with a single reagent. Clinical Chemistry, Salt Lake City, v. 29, n. 2, p. 372-374, 1983.

SCHLESINGER, S.; RUBIN, S. I. Serum bile acids and the assessment of hepatic function in dogs and cats. Canadian Veterinary Journal, Ottawa, v. 34, n. 4, p. 215 220, 1993.

SEAL, U. S.; ARMSTRONG, D. L.; SIMMONS, L. G. Yohimbine hydrochloride reversal of ketamine hydrochloride and xylazine hydrochloride immobilization of Bengal tigers and effects on hematology and serum chemistries. Journal of Wildlife Diseases, Lawrence, v. 23, n. 2, p. 296-300, 1987.

SHAW, L. M.; STROME, J. H.; LONDON, J. L.; THEODORSEN, L. International federation of clinical chemistry (IFCC). IFCC methods for the measurement of catalytic concentrations of enzymes. Part 4. IFCC method for gamma-glutamiltransferase. Journal of Clinical Chemistry and Clinical Biochemistry, Oxford, v. 21, n. 3, p. 633-646, 1983.

SHRIVASTAV, A. B.; SINGH, K.P.; MITTAL, S. K.; MALIK, P. K. Haematological and biochemical studies in tigers (Panthera tigris tigris). European Journal of Wildlife Research, Berlim, v. 58, n. 1, p. 365-367, 2012.

TALKE, H.; SCHUBERT, G. E. Enzymatsche hamstoffbestimmung in blut und serum in optischen test nach Warburg. Klin. Wochensh, Berlim, v. 43, n. 1, p. 174, 1965.

VELAPOLDI, R. A.; PAULE, R. C.; SCHAFFER, R.; MANDEL, J.; MURPHY, T. J.; GRAMLICH, J. W. $A$ reference method for the determination of chloride in serum. BNS Special Publication 260-267, US Department of Commerce, National Bureau of Standard, Washington D. C. U. S. Government Printing Office, 1979. BNS special publication 260-260, US Department of Commerce, National Bureau of Standard. Washington D.C., U.S.: Government Printing Office, 1978.

BNS special publication 260-263, US Department of Commerce, National Bureau of Standard. Washington D.C., U.S.: Government Printing Office, 1979.

WEAVER, L. J.; JOHNSON, M. R. Hematology and serum chemistry values of captive Canadian lynx. Journal of Wildlife Diseases, Lawrence, v. 31, n. 2, p. 212-215, 1995.

WIDMER, C. E.; HAGIWARA, M. K.; FERREIRA, F.; AZEVEDO, F. C. Hematology and serum chemistry of free-ranging jaguars (Panthera onca). Journal of Wildlife Diseases, Lawrence, v. 48, n. 4, p. 1113-8, 2012. 
